\title{
Towards Constructing Identity of a National University: "Our Past" at the Websites of Russian Universities
}

\author{
Valeria E. Chernyavskaya ${ }^{\text {a* }}$ \\ and Elena L. Safronenkova ${ }^{b}$ \\ ${ }^{a}$ Peter the Great St. Petersburg Polytechnic University \\ 29 Politekhnicheskaya Str., St. Petersburg, 195251, Russia \\ ${ }^{b}$ Northern Arctic Federal University \\ 17 Severnaya Dvina Emb., Arkhangelsk, 163002, Russia
}

Received 10.09.2019, received in revised form 23.09.2019, accepted 04.10.2019

This study explores the question how the concept of university identity may be suited to address the relationship between present and past. As two central notions social identity and reputation are discussed. We presume that reputation is a socially distributed representation that monitors social identity. The analysis provides that self presentation from the historical perspective serves as an efficient way of identification of the contemporary university. Addressing history is not only part of new promotional culture. This is a symbolic representation of the modern university's social embeddedness. The major implication is that the university acts a partner of the state. Historical reference acts as an ideological construction, $i$. e. a symbolic representation of values, concepts and arguments for achieving the goals of the university corporation as part of the Russian nationhood. Events of the past become the standard for positive evaluation and legitimization of its present functioning. We discuss the social embeddedness of Russian university based on the university websites presuming that the websites reflect the changing nature of discursive practices and provide evidence to monitor the values and identities they communicate.

Keywords: social identity, academic reputation, discourse analysis, social practice, history, Russian universities.

Research area: philology.

Citation: Chernyavskaya, V.E., Safronenkova, E.L. (2019). Towards constructing identity of a National University: "Our past" at the websites of Russian universities. J. Sib. Fed. Univ. Humanit. Soc. Sci., 12(10), 1819-1839. DOI: 10.17516/1997-1370-0491.

(C) Siberian Federal University. All rights reserved

* Corresponding author E-mail address: tcherniavskaia@rambler.ru ORCID: 0000-0002-6039-6305 (Chernyavskaya)

This work is licensed under a Creative Commons Attribution-NonCommercial 4.0 International License (CC BY-NC 4.0). 


\section{Introduction}

This paper has two central notions. The first one is identity. Identity refers to "who and what we are', that is a set of features which help to be identified by a certain community. Identity is an object of construction (Czarniawska, 2000; Hatch, Schulz, 1997; Molodychenko, 2017; Stensaker, 2015).

All subjects have identities, but some also have reputation. Thus the second notion to discuss is that of reputation. We presume a special social force in constructing our knowledge about the world and social reality - trust. The concept of reputation is in close connection with it, it is a major tool in understanding of social networks and rating systems. Reputation is defined as the generalized level of esteem, recognition and trust for an individual/ organization held by a stakeholder (Christensen, Gornitzka, Ramirez, 2019; Conard, Conard, 2000; Finch, McDonald, Staple, 2013). Thus reputation is social information, namely value-based information about people, institutions and processes that release information. It is in social interaction that there arises an evaluative dimension and social consciousness of the image of ourselves that we want to leave track of through actions in social practices.

We make therefore a conceptual distinction - identity is what a person or an institution stands for and wishes to be known for through identification with social roles, reputation is what a person or an institution is known for based upon past actions.

Reputation, then, is a socially distributed representation that monitors social identity. This vision of reputation as a social representation allows to correlate it with the concept of identity.

During a certain period of history and within the framework of a certain social and cultural practice there exists a set of standards and indicators which are used to define the concept of reputation, to form the image of a personality, social group or institution. Reputation integrates relevant features to be included in the reputational profile of a personality or an institution. In addition, the notion of reputation means being known for something according to certain significant criteria in professional and expert communities (Lange et al., 2010: 157). Thus reputation acts as an information filter which determines value-based attitude to a person or an institution.

We discuss social embeddedness of the university based on the university websites. We presume that the websites reflect the changing nature of discursive practices and the values and identities that they communicate (Chernyavskaya, 2019; Morphew, Hartley, 2006; Origgi, 2012b; Zhang, O’Halloran, 2013). 
The current paper is linked to this broad research interest. In particular it addresses how a focus on institutional identity is of relevance when studying the current challenges universities are facing, and how the concept of institutional identity may be well suited to address the relationship between continuity and change.

\section{Research questions}

In this regard this paper aims to answer the following broad question: How are institutional identity and academic reputation of a national university formed in the course of current social changes of the university corporation?

We intend to answer this question by providing answers to the following secondary questions:

How is historical past of the university used to construct its social representation?

How is historical past of the university discursively used and becomes a factor affecting social and semiotic (linguistic) constructing of the reputation and identity of the national university?

How is connection between the past and the present of the university established in the profile of the university? We intend to investigate how such coherence of the university discourse is created that makes one comprehend the facts of the past together with the current process of identification and new functions and missions of the university.

\section{Methodological analytical framework}

Theoretical framework is found in the discourse analysis in line with the performative turn and social constructionism that is a general trend in the humanities and social sciences. Reputation constructing is the cross point of modern communication theory, pragmatics, sociolinguistics, social semiotics and discourse studies. Against the bias towards structure, the performative approach puts emphasis on autonomy of social actors and action. The object of investigation is then a social practice, and it is regarded as discursive performance which is not dependent on abstract rules and patterns. At the same time constructionism principles act as a general methodological objective aimed at analyzing social practice recorded in texts as well as its value-based, cultural and linguistic specifics. Within the methodological position adopted, knowledge about the world and social networks is viewed as a social structure and social representation. The analysis of 'who and what you are' is dependent on purpose, context, social occasion, and involves semiotic resources of representation: symbols, narratives, textual design. 
The key mark of the constructionist approach is contextualization. We see context as a set of features both affecting and producing specific modes of social action. Contextualization means defining such features and social attributes that have clear and empirically provable characteristics.

This paper is structured as follows. First, we define the concepts of identity and reputation and consider their theoretical applications for analysis of university social self. Second, we consider social context in which the modern Russian university undergoes transformations resulting from newly set tasks. Third, we present the analysis of texts of the websites of 45 Russian universities: national research universities, federal universities and a number of pedagogical universities which have a long history as educational institutions. The following sections of the websites were studied: "History", "About the University". Access date to the websites is January to March 2019.

\section{Defining Identity and Reputation}

Identity is defined and analyzed as a set of features which help to be identified by a certain community. Identity always results from identification, i. e. from practical understanding of 'who and what' an individual or a collective subject is. The key premise that we rely on is: identities are constructed in practices that produce or perform identity, "identity is identification, an outcome of socially conditioned semiotic work" (Blommaert, 2005: 205). We presume that identities are created as "socially recognized points of view or attitudes" (Ochs, 1993: 296).

The identification presupposes choosing one viewpoint from the number of possible views. In defining the concept of identity we rely on considering identity as a process of constructing identity rather than a fixed permanent object (Molodychenko, 2017: 123). Social identity seems to be always realized through evaluation which helps to establish and maintain identity to a certain social group. A crucial role in constructing identity is given to linguistic and in a broader sense to semiotic means. A theoretical implication is that identity becomes a matter of details.

Processes of identification are investigated and distinguished in terms of personal and collective/social identities. The notion of corporate identity seems to be very wide: it includes an institutional strategy, which takes into consideration the prospects of its work in different areas, corporate design, as well as a corporate language or corporate wording. Events aimed at establishing corporate identity contribute to transforming of institutions into special mental and social cultures. Institutional identity defines, evaluates 
and legitimizes actions undertaken both by the institution and its workers in accordance with their corporate-related roles.

Stensaker (2015) points out two distinctive approaches to identity. One approach claims that organizational identity could be understood as reflecting a 'true' organizational character. Another approach defines organizational identity as a resource which could be applied as part of the strategic positioning and strategic orientation. One of the main differences between these approaches is the extent to which organizational identity is seen as something which can be applied as a management tool during change processes and thus can be constructed and manufactured through the use of language, symbols and myths to fit key strategic objectives (Stensaker, 2015: 104).

This research approach demonstrates the way how the notions of identity and reputation are interrelated. Reputation is seen as trustworthiness, that is the information about the social ties that say who you are and what you are known for. Reputation is a relation between a social actor and the set of its social and cultural representations. Cultural representations are culturally stabilized representations that have previously been attached to you, that have circulated about you and that are held by people. Having a reputation means being attached to an evaluative representation. Thus reputation is not only a rational choice of values and behaviour, but also a social and cultural notion that has to do with the way in which the social practice is organized (Origgi, 2012a: 409). Having a reputation means systematic, regular use of semiotic resources and symbolic representations in similar situations.

Management researchers relate reputation to the overall estimation in which an organization is held by its constituents, incorporating four key elements, including credibility, trustworthiness, reliability and responsibility (O'Loughlin et al., 2015: 807). The ultimate goal of any brand is to communicate credibility, legitimacy, and visibility to key stakeholders (Aaker, 2007). Institutional (corporate) reputation is regarded as a set of views about the institution, its resources, strategic goals, history as being implemented in a multifactor system of relationships in social context (Christensen et al., 2019: 6). It is projected through cultural and semiotic means, through branding and marketing.

Reputation is regarded as an information system which enables the process of evaluation to exist in the framework of a certain community. It allows to distinguish one object from a number of others and draw attention to it. The concept of reputation is composed of value features which shape its identification, for example, following ethic standards, responsibility. Thus reputation can be defined as social appraisal of 
an institution which has been gained and maintained long-term, as well as both the consequence and the result of its practice.

Reputation is commonly seen as the informational trace of repeated past actions. If actions are repeated, reputation may conventionalize in "seals of approval or disapproval" (Origgi, 2012a: 401). We take as a conceptual distinction - reputation is what an individual or an institution is known for based upon repeated past actions, whereas identity is what an individual or an institution stands for and wishes to be known for.

As applied to the university, the concept of identity is closely connected with academic reputation. It is thus of special interest that the university reputation is considered as a series of actions and other gestures which are representative and relevant within a certain community. One of information-bearing sources about the university reputation is its profile, including a mission statement, strategic goals, values which are presented on the websites, in rector's appeal, in local regulatory documents, etc.

There has been a notable shift towards analyzing reputation management within the framework of academic discourse in the recent decade. Modern methods of information generation and transfer have posed a number of tasks for the educational system in general and the management system of higher educational institutions in particular. The reputation is formed as affected by a number of managerial solutions and actions and marketing efforts. Researchers claim that management of the university reputation has been formed due to globalization trends in academic sphere. A prominent trend is formalization of universities which leaves them outside the national context and deprives of their unique characteristics. Reputation management has become a global fashion (Drori et al., 2013: 143).

Active reputational management, great efforts towards university's selfpresentation can be also regarded as a result of development of information society, intensity of information flows and new media-based formats. Our evaluations and decisions are embedded more and more in networked systems that provide us with ratings, as if information should be evaluated in advance. This creates an opportunity to reduce the cognitive deficit caused by a too wide offer of information. Reputation plays thus a key role in decision making processes. The university profile should be noticeable and outstanding in order to be recognizable. For this reason additional tools for its foregrounding in the common information space are to be used. Searching for new formats of self-expression has become the factor which provides maximum focus on the object under discussion, see for more details (Belyaeva, Chernyavskaya, 2016; 
Gasparyan, Cherniavskaia, 2014; Kulikova, Burmakina, 2016; Molodychenko, 2014; Nefedov, 2013; Yakovleva, 2018).

\section{Universities as social actors}

A key factor affecting transformations of a contemporary university in general and a Russian university in particular is more complex connections between the university and society. New tasks of the university are formulated in line with its 'third mission' (Gornitzka, Stensaker, 2014; Frank, Gabler, 2006; Kulikova, 2018; Mautner, 2005; Ramirez, Christensen, 2013). University 3.0 is engaged in technological entrepreneurship, shaping new markets on the national scale. Major consequences of managerialism ideology can be summarized as follows. The university has become part of a complex system which is externally regulated and governed rather than by inner academic hierarchy and expertise. As a social institution the university has begun to compete for external resources, support of the government and private companies. External agents appeared to be tightly integrated in the management system of the university and its administrative hierarchy as well as decision-making processes which determine academic, research and innovative components. Discursive practices associated with marketization are found extensively in the higher education. It is also found that mission statements construct university brands by shifting management from academic values toward corporate ones (Chernyavskaya, 2019; Mautner, 2005).

The marketization means more than just a change in rhetoric. It brings about fundamental shifts in university strategy and practices. The way these shifts are reflected in the university websites is the central issue for this study.

Since mid 2000s changes in the system of higher education have put emphasis on universities as drivers of further development. It is development of national universities of international level that reflects the state ambitions to be the leader in the world. The hierarchy of Russian universities has been enhanced and fixed. There are leading prestigious universities in modern Russia: 29 national research universities with research regarded as a core mission equal to teaching, 10 federal universities and universities which received the status of "the unique centre of research and education", namely Lomonosov Moscow State University and St. Petersburg State University. There are also other types of higher educational institutions. The state provided focused support of leading higher educational institutions and organized a competition of national research universities. They also introduced programme of international excellence "5-100-2020", which allowed for achieving by a number of Russian universities the 
highest level of international visibility in key rating systems. An important change is implementation of managerial practices of organization, control and rating systems of performance and efficiency of Russian science. The university is supposed to be managed by methods similar to those applied to business corporations and business projects. Organizational model with a key notion in defining obligation model being efficiency of university-based science became to be implemented and widely exercised.

Today's institutional image and collective identity of the university are established and maintained as a process of branding and constructing the image externally rather than by retaining inner traditions which are held down within departments, scientific schools in terms of mentor-disciple and so on. Public image has become an effective tool of maintaining social recognition and agreement on the role of the university, legitimacy of its mission and ambitions. This is closely related to achieving a number of strategic goals. These include having access to various kinds of resources, taking active part in redistribution of resources, clarifying and legitimizing of its own objectives for both external and internal experts.

In this regard, one of the complex tasks in the management of the university identity is to find balance between forming an external image of the university in social sphere (for example, setting up professional associations; publishing newspapers and journals; organizing conferences and seminars, etc) and powerful corporate culture within the university. The latter is formed through formulating a mission statement and values, incorporating a corporate code; building interrelationships between members of the staff in line with the values claimed. Therefore, constructing the identity presupposes the use of tools and symbols which can be conceived and recognized by a collective addressee. They should also have impact on the message sender. This perspective becomes crucial for our purposes when identity is considered as a form of social and symbolic capital, that confers status and distinction, as formulated by Pierre Bourdieu.

\section{Past records in communicating the actual mission}

Constructing a positive vision on past actions is a tool to construct and evaluate present social position. Time is seen as an advantage for earning reputation. Reputation is thus the anticipation of future actions based on past behaviour. Past records are a signal of future intentions.

Self-presentation of a modern university presupposes formulating the mission, major competences and introducing the achieved and expected outcomes. The latter is often formulated as the image of the present and the image of the future. We see one 
more component of significant importance in constructing the image, namely arranging of historical context of the university activity, its vision of the past. Prolongation of the "road map" both in the future and the past has become a special instrument of constructing the university identity.

In general, historical past becomes the object of research in the humanities and is beyond the scope of investigation in historiography, for more detail see (Chernyavskaya, 2016). Shared memories play a central role in social practices. They are usually based on collective cultural knowledge of a shared past among group members. Welzer (2008) claims that processes in memory making must be thought of as dynamic and situated social interactions. Communicating memories is an interactive, interpersonal and social phenomenon sustained by social agreement. That is, the communicating past experiences is not driven by the mere transmission of narratives of the past, but also by a situated reconstruction of those experiences in the present, depending on social group goals and pragmatic needs, e. g. the construction of a positive in-group self-representation (Molodychenko, 2017: 125-126). That is why social remembering is always a dynamic action-oriented reconstruction of the past.

The past is thus viewed as a resource. The past serves as a resource of ideology, a resource of politics, a resource and an efficient instrument of constructing identity and identification of a certain personality, social group. History as knowledge about the past appeared to be pragmatized to a greater extent, i. e. involved in various social practices. History is part of artistic and aesthetic learning through rhetorical colours and imagery of reality. History is also regarded as part of didactic and moralizing discourse being part of various spheres of ideology — politics, religion and corporate fields. These practices address the past with a certain order for demonstration of their own goals and projects.

Beliefs about the trustworthiness of past create 'the image of reality' or 'reality effect' acting as intermediaries between participants of communication and real facts. A certain view of 'how things happened' created by linguistic means foregrounds the concept of 'history regarded as the present', returns the past in current practice.

With perspective of the university as a social institution, the past is considered and analyzed mainly as a university tradition, and this notion is recognized by scholars as contradictory and vague. The concept of 'a university tradition' is dynamic rather than static, and it is actively restructured and instrumentalized bending to exterior politically- and ideologically-based consequences. University memory acts as a tool and an important resource of self-legitimization in self-esteem practices. 


\section{Results and Discussion}

Self-presentation in terms of historical traditions is a common feature of Russian universities today. The websites of most of the universities contain the following sections - 'History; History, traditions and goals'. In what follows we will consider the examples borrowed from the English language texts of the English versions of the websites, i. e. they contain authentic English phrases in the profiles of the universities.

Analysis of the text collection has revealed the following. There are several leading universities that provide its historical background starting from the present day times. It should be noted that in 2000 a lot of Russian universities were granted the status of federal or national research university after several institutes were united into one university centre. This very moment is regarded as a starting point of their history. For instance, Siberian Federal University provides the following information in section 'History of SibFU':

a) 2006-2007 years

November 4, 2006 The Prime Minister of Russia Mikhail Fradkov signed a decree to rename Krasnoyarsk State University into "Siberian Federal University" merging it with the following educational institutions: Krasnoyarsk State Architectural and Construction Academy, Krasnoyarsk State Technical University and the State University of Nonferrous Metals and Gold.

November 8, 2006 the website of SibFU was launched.

Similarly, Northern Arctic Federal University refers to modern times when presenting its history in section History:

b) Set up on the basis of Arkhangelsk State Technical University, the Northern (Arctic) Federal University named after M.V. Lomonosov (NArFU) is a higher educational institution established by RF President Dmitry Medvedev's Decree dd. 8 June 2010. Among NArFU's historical landmarks is the year 2011 - the period of its formation. In May, the university was joined by Pomor State University, Peter the Great Forestry Engineering College in Arkhangelsk and Severodvinsk Technical College.

The Herzen State Pedagogical University of Russia founded as an educational institution in 1797, marks its history on its website from 1991 "when Leningrad State Pedagogical Institute named after A.I. Herzen was given university status and was called the Herzen State Pedagogical University of Russia".

Another trend, namely extending the historical context back to the maximum, to the moment of the institution foundation as a starting point of its reputation can be 
noted. The analysis has indicated that 31 out of 45 Russian universities under discussion present their history in a similar way.

The historical record in the presentation of the modern university is constructed as a multimodal structure relying on different text genres and various verbal and visual formats.

\section{Semiotic representation of 'our history'}

In the sections of the websites in question we can find the following: history of the university name, biographies of the first rectors and outstanding people, historical documents, excerpts from the letters and speeches of the university contemporaries, people who witnessed its development, newspaper articles of the previous years, memoirs of patrons, graduates.

Historical photos of the buildings, people related to the university - rectors, professors, outstanding students, original architectural plans of the university buildings, photos of manuscripts and authentic models of inventions, which demonstrate the university's involvement in the key milestones of the country's history are posted on the websites.

Let us illustrate this with the following example. The website of Peter the Great St. Petersburg Polytechnic University contains section ‘Our History’ which is designed like this. The first page (Fig. 1) shows three edge-to-edge photographs: one of them portrays the members of the first university board headed by the first rector, Prince A. Gagarin in 1902; the other photo depicts the present-day students, members of the Historical Club "Our Polytech" who have created an electronic "Memory book" and save the information about the University staff and students who died during the Second World War. A young man is holding a red flag which symbolizes the Soviet

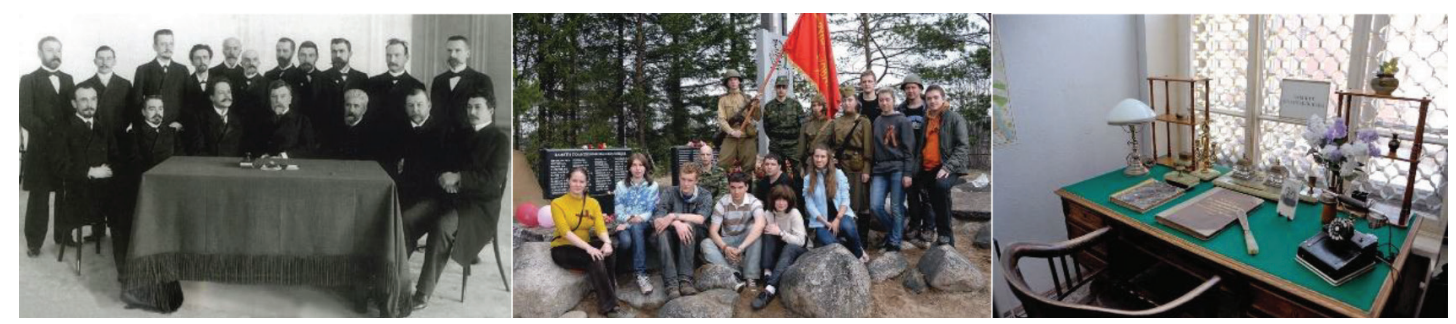

Fig. 1. Peter the Great St. Petersburg Polytechnic University homepage in 2019. Available at: https://english.spbstu.ru/university/about-the-university/history/

Retrieved February 15, 2019 
Union and the victory in the Second World War. The flag becomes as a visual focus in the reader's perception. The third picture shows a museum exhibit, a desk of the first prominent engineers-researchers. This visual sequence allows to continuously evaluate both the past and the present, targets specifically at accomplishments and merits in the past. The image of the present is thus implied here. The present is consistent with the past, academic achievements and symbols are closely related to breakthroughs and wins of the society in general.

Fig. 2 shows section 'History' on the website of St. Petersburg State Economic University. The section is chronologically arranged as it mentions the university's major milestones starting from 1902 when the first Russia's economic department was established up to the present-day era of the university as a federal institution. Key events in the country history are displayed as major moments of the university history. The following historical scenes are highlighted: the university in the period of the World War II (1941-1945), the university during the siege of Leningrad, the university in the era of industrial recovery and further major breakthroughs in the national economy. The text is accompanied by visual arguments - numerous authentic documents, such as the photo of the destroyed building in 1944, a view of Leningrad Financial and Economical Institute, a pass to besieged Leningrad after air alert, the decree on resuming work of Leningrad Financial and Economical Institute in 1944.

The analysis has found that reference to the past while constructing the image of the university is made by two interconnected communicative and speech techniques. These include reference to inner traditions of the university drawing on its own context and reference to exterior context and the role of the university on a nationwide scale.

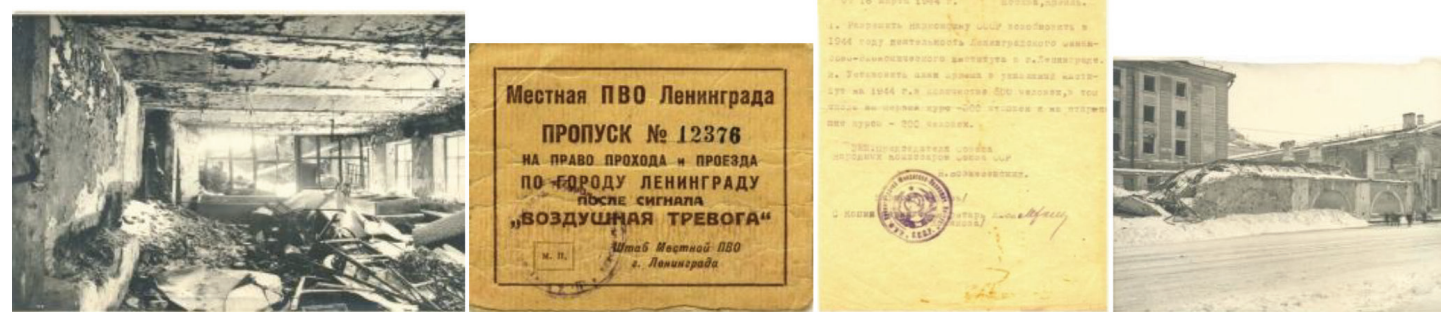

Fig. 2. St. Petersburg State Economic University homepage in 2019. Available at: https://unecon.ru/ob-universitete/history. Retrieved February 15, 2019 
Let us refer to the following examples:

c) On May 28, 1878, Emperor Alexander II signed a decree on the establishment of the first and only higher education institution in the vast expanses from the Russian Urals to the Pacific Ocean - the Siberian Imperial University in Tomsk...This day ended the 75-year-old epic struggle for the foundation of a university in Tomsk and began the history of the building, opening and further development of Tomsk State University - the ninth in Russia and the first higher education institution in Siberia.

The Imperial, now Tomsk State University, has had a decisive influence on the formation of science, education and culture in the Asian part of Russia and is considered one of the nation's leading universities.

d) Due to its vast resources Siberia has always been and remains the essential region for all of Russia. Following this simple logic, Novosibirsk Akademgorodok was established in the heart of Siberia, and in a short while Novosibirsk State University became its most valuable and integral part.

e) July 9, 1899 - issued a decree of the Russian Emperor Nicholas II on the opening of Oriental Institute in Vladivostok, the first classical higher educational institution in Eastern Siberia and the Far East of the country. October 21, 1899 -Oriental Institute was inaugurated and Alexei Pozdneev, Professor of the St. Petersburg University Oriental Languages Department, State Counsellor, was appointed as the first Rector.

2010-2011 - Far Eastern Federal University (FEFU) was established as a result of the merger of four leading universities in the Far East: Far Eastern National University (FENU), Far Eastern State Technical University (FESTU), Pacific State Economic University (PSUE) and Ussuriysk State Pedagogical Institute (USPI). The relevant decree was signed by the President of Russia.

Linguistic choices with the meaning of priority are of great importance here, namely priority in quality — 'to be the best' and priority in time with the meaning of 'being the first', cf. the following examples in the above mentioned contexts: the first; the most; the first and only.

It is also involvement of the university in the life of the country from historical perspective that is stressed in its profile. Chronological markers are allied with space markers by intensifying each other. As exemplified in the examples above and further: from the Russian Urals to the Pacific Ocean; in the Asian part of Russia in Siberia; in the heart of Siberia; in Eastern Siberia and the Far East.

Text sections representing the past provide coherence which enables to associate the success and reputation of the university with incremental advance of the country. 
A wide use of verbs and nouns with the meaning of development, advancement, a breakthrough can be found in the texts - achievement, to develop, to continue; meaning of value and positive significance of the outcomes - success, prominent, new, dynamic; meaning of an organizational role of the university as a driving force of transformations - to provide, to contribute. Nomination of the university appears to be used in the same context as nomination of the country, state, Russia - from formalgrammatical perspective as part of syntactic structure and in terms of meaning as part of a whole. The effect of continual achievements and positive valued-based meanings is produced. Excerpts f-h explicitly note that:

f) Ural Federal University is the oldest higher educational institution in the Ural region... After some time the University split into two: Ural State University, specializing in fundamental, natural and mathematical sciences, humanities and social studies, and Ural Polytechnic Institute which was essentially focused on training engineers for metallurgical, heavy engineering, construction, radio technology and power engineering industries. UPI was also engaged in the dynamic development of the knowledge areas which were new for the USSR back then: nuclear power engineering, organic chemistry, telecommunication technologies.

g) In the late 50s Siberia provided the country with $75 \%$ of coal and possessed $80 \%$ of its hydropower resources. Siberia quickly became industrial, but science was largely the applied type which did not satisfy the needs. To pursue fundamental science they needed a new type of professional. They needed a lot of potential employees that corresponded to this new profile. Thus, Novosibirsk State University was born.

h) Peter the Great St. Petersburg Polytechnic University... was founded in early 1899. It emerged during the period of the economic and cultural boom that took place at the turn of the $20^{\text {th }}$ century and became one of the factors contributing to further successful development of the country. Half a century later, the University was acknowledged not only as a prominent higher education establishment, but also as a significant Russia's cultural achievement of the early $20^{\text {th }}$ century.

A profound rhetoric effect is produced by addressing the canon of the Russian imperial university. The modern Russian university portrays itself as an heir and successor of the imperial traditions of the Russian university. Historical retrospective is extended far back in the past, the image of the past becoming more comprehensive, prominent and powerful. Two Russian universities seem to be more illustrative in this regard - Tomsk State University which marked its $140^{\text {th }}$ anniversary in 2018 and Peter the Great St. Petersburg Polytechnic University which celebrates its $120^{\text {th }}$ anniversary 
in 2019. Both universities have been ranked as national research universities since 2010 and play a leading role on national and international arena. Arrangement and extension of the historical context of their work serves as a noticeable feature in sustaining the universities' reputation. The most detailed and extensive sections with numerous documentary records, profiles, etc. presented on the university websites are sections about historical past of the university. For example, Tomsk State University published authentic historical documents of the $19^{\text {th }}$ century, including the code and regulations for the students of the Imperial Tomsk University preserving authentic spelling and stylistics of the text of those times.

Management of St. Petersburg Polytechnic University invoked change in the name of the university, and in 2015 by the order of the Ministry of education and science of the Russian Federation the university was renamed into Peter the Great St. Petersburg Polytechnic University. By doing this, the standard of measuring the status and image of the university was set - glorious past of the Russian state and its grand reformer emperor Peter I.

The history section of Kazan Federal University is marked by heading "From Imperial to Federal". A similar trend can be observed on the website of Saratov State University: "Saratov State University: From Imperial University to National Research University".

Remarkably, similar effect of extension of historical retrospective is achieved in the profile of National Research University Higher School of Economics (HSE). This university founded in 1992 in the period of the reforms of the Russian society, is considered the highly reputed leading university both nationwide and abroad. It successfully incorporates principles of a new university in Russia, establishes a strong corporate culture and high standards of academic and innovation work. It is remarkable to note that in 2003 the university introduced the status of an ordinary professor and set up the board of ordinary professors. One can find historical record about the status of an ordinary professor in the History section on the website of the university. This position existed in pre-revolutionary Russia, when an ordinary professor was the highest nonadministrative position at a university. Today the position does not exist in any of the Russian universities, only HSE has one. The position of an ordinary professor has emerged as a status which is associated with academic freedom and stability. A clear allusion referring to the historical tradition of the Russian imperial university and at the same time a hybrid between tenure and another western concept - professor emeritus marks the historical context of an innovatively functioning university and 
extends its past. The board was founded to promote the expert opinion of the elite scientific community and to act as an institution whose views could be heard by the management of HSE. The Board allows for HSE's leadership to hear expert opinions from the university's best.

\section{Conclusion and Implications}

Self presentation from the historical perspective serves as an efficient way of identification of the contemporary university. The past serves as a resource and an efficient tool of constructing identity, namely credibility and visibility. History sells. History in general is a selling thing in promotional practices to push places and institution to consumers. Celebrity effect is another resource to add to the credentials and prestige to recruit students, to get access to financial support from external companies. Relying on historical record acts as a special marketing vehicle: when promoting its educational services and scientific innovations the university is positioned as the one continuing long-standing traditions which are handed down through generations. The past achievements pictured along with positive appraisal and positive evaluation meanings are part and parcel of the evaluation of the contemporary image and mission of the university. Orientation towards the past achievements to a certain extent reflects notorious biases in social networks, such as the Matthew effect as identified by Robert Merton, according to which those who are more prominent have to earn more recognition and more reputation.

By claiming that, we would like to point out a specific feature common for the Russian universities. Addressing history is not exclusively part of new promotional culture. This is a symbolic representation of the modern university's embeddedness in the government policy. The major implication is that the university acts a partner of the state.

Description of the past is regarded as the history of memory. To a certain degree it is preserved by operating the facts related to historiographic chronology of events, people's biographies, a set of achievements and outcomes. However, the fact-based component is of low priority. Pragmatic effect plays a vital role, namely historical reference acts as an ideological construction, i. e. a symbolic representation of values, concepts and arguments for achieving the goals of the university corporation as part of Russian nationhood. Events of the past become the standard for positive evaluation and legitimization of its present functioning. Our observation that sections like 'History', 'Historical background' and reference to the past in general are shown in a detailed 
and profound manner in Russian, is in favour of this statement. Glorification of the past, amplified image and scale of the past reveal modern trend of the Russian national university towards the Russian consumer of information and educational services. In contrast, the English texts posted in the corresponding sections of the English website mostly look shorter, more compact and contain only key dates and statements. There are also universities like St Petersburg State University of Economics whose English versions of the website do not provide any historical background, whereas their Russian versions provide more detailed information about the past.

Having a history has become part of the university identity, marker of its collective self-presentation and reputation. The past allows to bring into pragmatic focus the following features of the contemporary Russian university. Firstly, the university is presented as a driving force of the country's development. The establishment and development of the university affected the changes that took place in the city, region and country as a whole. Development of the country and the university is shown as a unidirectional event. By building its external image and social embeddedness the university stresses 'from local to international status' coordinate system. Secondly, the university presents itself as contributing to the development of the scientific branch, national science as a whole. The established image of the past brings into focus incremental growth path 'from individual achievements to the worldwide outcomes'.

\section{References}

Aaker, D. (2007). Brand it or lose it. In California Management Review, 50(1), 8-24.

Belyaeva, L.N., Chernyavskaya, V.E. (2016). Evidence-based linguistics: methods in cognitive paradigm. In Voprosy Kognitivnoy Lingvistiki, 3, 77-84. DOI: 10.20916/1812-3228-2016-3-7.

Blommaert, J. (2005). Discourse: A Critical Introduction. Cambridge: Cambridge University Press, 299 p.

Chernyavskaya, V.E. (2016). Historical Past as a Textual Reality: a linguistic approach in historical narrative and its methodological implementation. In Vestnik Tomskogo Gosudarstvennogo Universiteta. Philologiya [Tomsk State University Journal of Philology], 3, 76-87. DOI: 10.17223/19986645/41/7.

Chernyavskaya, V.E. (2019). Corpus-Assisted Discourse Analysis of Russian University 3,0 Identity. In Vestnik Tomskogo gosudarstvennogo universiteta. Filologiya [Tomsk State University Journal of Philology], 58, 97-114. DOI: 10.17223/19986645/58/7. 
Christensen, T., Gornitzka, E., Ramirez, F.O. (ed.) (2019). Reputation Management, Social Embeddedness and Rationalization of Universities. In Universities as Agencies. Reputation and Professionalization. Palgrave Macmillan (eBook), 3-43. DOI: 10.1007/978-3-319-92713-8.

Conard, M.J., Conard, M.A. (2000). An Analysis of Academic Reputation as Perceived by Consumers of Higher Education. In Journal of Marketing for Higher Education, 9: 4, 69-80, DOI: 10.1300/J050v09n04_05

Czarniawska, B. (2000). Identity Lost or Identity Found? Celebration and Lamentation Over the Postmodern View of Identity in Social Science and Fiction. M. Schultz, M. J. Hatch, M. Holten Larsen (Eds.). In The Expressive Organization. Linking Identity, Reputation and the Corporate Brand. Oxford: Oxford University Press.

Gasparyan, G.R., Cherniavskaia, V.E. (2014). Text as Co-existance in Discourse. In Voprosy Kognitivnoy Lingvistiki, 4 (41), 44-51.

Drori, G., Delmestri, G., Oberg, A. (2013). Branding the University: Relational Strategy of Identity Construction in a Competitive Field. P. Scott, L. Engwall (Eds.). In Trust in Higher Education Institutions. London: Portland Press, 134-147.

Finch, D., McDonald, S., \& Staple, J. (2013). Reputational interdependence: an examination of category reputation in higher education. In Journal of Marketing for Higher Education, 23: 1, 34-61, DOI: 10.1080/08841241.2013.810184

Frank, D., Gabler, J. (2006). Reconstructing the University: Worldwide Changes in Academic Emphases Over the $20^{\text {th }}$ Century. In Stanford, CA: Stanford University Press.

Gornitzka, E., Stensaker, B. (2014). The Dynamics of European Regulatory Regimes in Higher Education: Challenged Prerogatives and Evolutionary Change. In Policy \& Society: Journal of Public, Foreign and Global Policy, 33(3), 177-188.

Hatch, M.J., Schultz, M. (1997). Relations Between Organizational Culture, Identity and Image. In European Journal of Marketing, 31, 356-365.

Kulikova, L.V. (2018). Strategic Partnership for the Future of Communication Studies in Russia: Siberian Federal University (SIBFU). In Russian Journal of Communication, 10: 1, 99-100. DOI: 10.1080/19409419.2018.1444432

Kulikova, L.V., Burmakina, N.G. (2016). Construction of Credibility in the Genre of Scientific Articles. In Pragmalinguistica, 24, 122-132, DOI: 10.1080/19409419.2018.1444432 
Lange, D., Lee, P.M., \& Dai, Y. (2010). Organizational Reputation: A Review. In Journal of Management, 37(1), 153-184.

Mautner, G. (2005). The Entrepreneurial University: A Discursive Profile of a Higher Education Buzzword. In Critical Discourse Studies, 2 (2), 95-120.

Molodychenko, E.N. (2017). Identichnost' i diskurs: ot sotsial'noy teorii k praktike lingvisticheskogo analiza [Identity and Discourse: From Social Theory to Practice of Discourse Analysis]. In Nauvhno-tehnicheskiie vedomosti Sankt-Peterburgskogo politehnicheskogo universiteta. St. Petersburg State Polytechnic University Journal. Humanities and Social sciences [St. Petersburg State Polytechnic University Journal], 8 (3), 122-133. DOI: 10.18721/Jhss.8312.

Molodychenko, E.N. (2014). Cognitive modelling of emotion-targeted persuasion. In Voprosy Kognitivnoy Lingvistiki, 3, 78-85.

Morphew, C.C., Hartley, M. (2006). Mission Statements: A Thematic Analysis of Rhetoric Across Institutional Type. In The Journal of Higher Education, 77(3), 456471.

Nefedov, S.T. (2013). Prototipicheskaya model' teksta kak osnova tekstotipologicheskogo znaniya (na materiale avtorskogo predisloviya $\mathrm{k}$ nauchnoy monografii) [The prototypical text model as the basis of text typological knowledge (based on the author's preface to scientific monograph)]. In VestnikSankt-Peterburgskogo universiteta. Seriya 9: Filologiya. Vostokovedenie. Zhurnalistika [Vestnik of Saint Petersburg University. Language and Literature], 3, 198-204.

Ochs, E. (1993). Constructing Social Identity: A Language Socialization Perspective. In Research on Language and Social Interaction, 26(3), 287-306.

O'Loughlin, D., MacPhail, A., Msetfi, R. (2015) The rhetoric and reality of research reputation: 'fur coat and no knickers', Studies in Higher Education, 40:5, 806-820, DOI: 10.1080/03075079.2013.842224.

Origgi, G. (2012a). A Social Epistemology of Reputation, Social Epistemology. In A Journal of Knowledge, Culture and Policy, 26: 3-4; 399-418, DOI: 10.1080/02691728.2012.727193

Origgi, G. (2012b). Designing wisdom through the web. Reputation and the passion of ranking. H. Landermore and J. Elster (ed.). In Collective wisdom, 38-56. Cambridge: Cambridge University Press.

Ramirez, F.O., Christensen, T. (2013). The Formalization of the University: Rules, Roots, and Routes. In Higher Education, 65(6), 695-708. 
Stensaker B. (2015). Organizational identity as a concept for understanding university dynamics. In Higher Education, 69(1), 103-115. DOI 10.1007/s10734-0149763-8.

Veloutsou, C., Lewis, J.W., Paton, R. (2004). University Selection: Information Requirements and Importance. In International Journal of Educational Management, 18(3), 160-171.

Welzer, H. (2008). 'Communicative Memory'. A. Erll and A. Nunning (ed.). In Cultural Memory Studies: An Interdisciplinary Handbook, Berlin, New York: Walter de Gruyter, 285-297.

Yakovleva, A.F. (2018). Istoriko-politicheskoye znacheniye «sotsial'nogo povorota» v filosofii nauki: aktual'nyye diskussii [Historical and political significance of the "social turn" in the philosophy of science: topical discussions]. In Dialog so vremenem [Dialog with Time], 65, 383-389.

Zhang, Y., O’Halloran, K.L. (2013). Toward a global knowledge enterprise: university websites as portals to the ongoing marketization of higher education. In Critical Discourse Studies, 10 (4), 468-485. DOI: 10.1080/17405904.2013.813777

\title{
Создавая идентичность национального университета: «Наше прошлое» на сайтах российских вузов
}

\author{
В. Е. Чернявская ${ }^{a}$, Е. Л. Сафроненкова ${ }^{\sigma}$ \\ ${ }^{a}$ Санкт-Петербургский политехнический \\ университет Петра Великого \\ Россия, 195251, Санкт-Петербург, ул. Политехническая, 29 \\ ${ }^{6}$ Северный (Арктический) федеральный университет \\ им. М. В. Ломоносова \\ Россия, 163002, Архангельск, наб. Северной Двиньл, 17
}

\begin{abstract}
Университетская идентичность рассматривается как комплексное понятие, ключевыми характеристиками которого выступают идентификачия с соичиальной ролью в обществе, а также значимость символических и семиотических ресурсов для конструирования идентичности. Цель публикации - показать, как на современном этапе сочиально обусловленных изменений российской университетской корпорации формируется связь университета и государства. Избран особый ракурс анализа и исследовательский вопрос о том, как историческое прошлое университета становится фактором сочиального и языкового конструирования образа национального университета в настоящем. Таким образом, в аналитической перспективе сближаются понятия институцииональной идентичности и академической репутации. Последняя
\end{abstract}


рассматривается как существующее в обществе оценочное восприятие университета на основе повторяюшихся действий в прошлом. Репутация означает в том числе узнаваемость в профессиональном и экспертном сообществе по существенным основаниям, анализируется как социальная репрезентация институции или личности. Обращение к образу прошлого в самопрезентации объясняется в том числе практикой маркетизации и состязательности, в которые включен современный российский университет в мировом контексте. Одновременно анализ констатирует иную характеристику, а именно, образ прошлого как иееностно-ориентированный идеологический конструкт, представляющий университет как часть российской государственности. Анализ подчеркивает актуальность и прикладную значимость дискурсивного анализа в связи с перформативной и конструктивистской ориентацией в изучении сочиальных практик.

Ключевые слова: социальная идентичность, академическая репутаџия, дискурсивный анализ, социальная практика, российский университет.

Научная специильность: 10.00.00 - филологические науки. 